\title{
Dynamic association of IKBa to chromatin is regulated by acetylation and cleavage of histone $\mathrm{H} 4$
}

Laura Marruecos ${ }^{1, *}$, Joan Bertran ${ }^{2, *}$, Daniel Álvarez-Villanueva1, Martin Floor ${ }^{2,3}$, María Carmen Mulero ${ }^{1,4}$, Anna Vert ${ }^{1}$, Yolanda Guillén ${ }^{1}$, Sara Arce ${ }^{1}$, Laura Batlle $^{5}$, Jordi Villà-Freixa ${ }^{2,3}$, Gourisankar Ghosh ${ }^{4}$, Anna Bigas ${ }^{1, \&}$ and Lluís Espinosa $^{1, \&}$.

${ }^{1}$ Cancer Research Program, Institut Mar d'Investigacions Mèdiques, CIBERONC, Hospital del Mar, Doctor Aiguader 88, Barcelona 08003, Spain ${ }^{2}$ Faculty of Science and Technology, Bioinformatics and Medical Statistics Group, University of Vic - Central University of Catalonia, Vic 08500 Spain ${ }^{3}$ Faculty of Medicine and Health Sciences, Universitat Internacional de Catalunya, Sant Cugat del Vallès 08195, Spain

${ }^{4}$ Department of Chemistry \& Biochemistry, University of California San Diego, 9500 Gilman Drive, La Jolla, CA, 92093, USA.

${ }^{5}$ Tissue Engineering Unit. Center for Genomic Regulation (CRG). Doctor Aiguader 88, Barcelona 08003, Spain

\footnotetext{
"Equally contributed

\& Corresponding authors

E-mail: abigas@imim.es; lespinosa@imim.es
} 


\section{ABSTRACT}

IKBs exert a principal function as cytoplasmic inhibitors of the NF-kB transcription factors. Additional functions for IKB homologues have been described including association to chromatin and transcriptional regulatioin. Phosphorylated and SUMOylated IKBa (pS-IKBa) binds histones $\mathrm{H} 2 \mathrm{~A}$ and $\mathrm{H} 4$ in the stem and progenitor compartment of skin and intestine, but the mechanisms controlling its recruitment to chromatin are largely unstudied.

We here show that serine 32-36 phosphorylation of $1 \mathrm{kBa}$ favors its binding with nucleosomes and demonstrated that $\mathrm{p}-\mathrm{I} \mathrm{KBa}$ association to $\mathrm{H} 4$ is favored by acetylation at specific $\mathrm{H} 4$ lysine residues. N-terminal tail of $\mathrm{H} 4$ is lost during intestinal cell differentiation by proteolytic cleavage at residues 17-19 imposed ny trypsin or chymotrypsin, which interferes $\mathrm{p}$-IkBa binding. Paradoxically, inhibition of trypsin and chymotrypsin activity in HT29 cells increased p-IkBa chromatin binding and impaired goblet cell differentiation, comparable to IKBa deletion. Together our results indicate that dynamic binding of IKBa to chromatin is a requirement for intestinal cell differentiation and provide a molecular base for the restricted nuclear distribution of $\mathrm{p}-\mathrm{I} \mathrm{KB} \alpha$ at specific stem cell compartments. 


\section{INTRODUCTION}

Cytoplasmic IKB proteins play an essential role as negative regulators of the NF-kB pathway, which controls immune responses and inflammation from hydra to mammals (Hoffmann and Akira, 2013). Canonical activation of NF-kB is initiated by stimuli such as TNFa, IL1 $\beta$ or LPS and requires IKB kinase (IKK)induced phosphorylation and subsequent ubiquitination-mediated degradation of the IKB inhibitors. Alternative nuclear functions for various IKB and IKB-like family members including IkBa (Arenzana-Seisdedos et al., 1997; Marruecos et al., 2020; Mulero et al., 2013), ІкBß (Rao et al., 2010), IkBNS (Hirotani et al., 2005) or Bcl3 (Bours et al., 1993) have been reported. The molecular mechanisms that dictate these moonlighting nuclear functions remain understudied.

Previous studies from different groups (Culver et al., 2010; Desterro et al., 1998; Hendriks et al., 2014; Marruecos et al., 2020; Mulero et al., 2013) demonstrated that a fraction of the IKBa protein is SUMOylated at the same K21 residue that, when ubiquitinated, triggers IKBa degradation. Thus, SUMOylated$\mathrm{IKBa}$ is primarily protected from degradation even in its phosphorylated form and independent of stimuli such as TNFa (Mulero et al., 2013). Phosphorylated and SUMOylated $I \kappa B \alpha(p S-I \kappa B \alpha)$ is localized in the nucleus of basal layer keratinocytes (Mulero et al., 2013) and in the intestinal crypt compartment (Marruecos et al., 2020), where stem and progenitor cells of both tissues reside, to regulate cytokine-dependent activation of a subset of polycomb repression complex (PRC) 2 target genes (Marruecos et al., 2020; Mulero et al., 2013). SUMOylated IkBa shows reduced association with NF-kB factors (Culver et al., 2010; Mulero et al., 2013), but efficiently binds the N-terminal tail of histones, in particular $\mathrm{H} 2 \mathrm{~A}$ and $\mathrm{H} 4$. In fact, binding of $\mathrm{I} \mathrm{KB} \alpha$ to histones precludes its subsequent association with NF-kB factors (Mulero et al., 2013).

Histones are an essential structural and regulatory element of the chromatin and they are organized in a highly stable structure called nucleosome. Nucleosomes are formed by several subunits of histone $\mathrm{H} 2 \mathrm{~A}, \mathrm{H} 2 \mathrm{~B}, \mathrm{H} 3$ and $\mathrm{H} 4$ tightly associated with DNA. Importantly, the $\mathrm{N}$-terminal tail of histones is flexible and protrudes outward the nucleosome, which makes histones accessible to editing enzymes that decorate their tails with a high variety of post-translational modifications (PTMs). PTMs can be dynamically added and 
removed thus modulating gene activation, silencing, chromatin accessibility, replication and DNA repair, in part by association with a plethora of non-histone proteins including transcription factors. Prototypical examples of proteins that specifically recognize PTMs in histones are the bromodomains (BRDs) and the BET (bromodomains and extra-terminal) family of proteins. BETs bind specific (Ac) $\mathrm{K}$ residues of histones in active regulatory domains such as promoters and enhancers (Filippakopoulos et al., 2012).

We here studied the molecular requirements for $\mathrm{pS}$-IkBa binding to chromatin, the residues involved in $\mathrm{pS}-\mathrm{I} \mathrm{KB} \alpha$ to histone $\mathrm{H} 4$ interaction, and the mechanisms that impose restricted $\mathrm{pS}-\mathrm{I} \mathrm{kBa}$ distribution in the stem cell compartments of the skin and intestine.

\section{RESULTS}

Hydrophobic interactions mediate $\mathrm{p}-\mathrm{IKB} \alpha$ association to histone $\mathrm{H} 4$.

Histones are basic proteins, and their positive charges determine association with the DNA. We investigated the possibility that electrostatic forces exert a major role in the observed association of IKBa with histones. We found that fulllength (FL) and two different amino-terminal IKBa fragments (aa1-200; aa20206) robustly interacted with histone $\mathrm{H} 4$ even at high salt concentrations $(300 \mathrm{mM} \mathrm{NaCl})$ (Figure S1A), indicating the involvement of hydrophobic forces in histones-IkBa binding. We aimed to confirm the stability of the interaction by Fast Protein Liquid hㅡromatography (FPLC) analysis of IkBa and histone H4 complexes. However, histone $\mathrm{H} 4$ was highly degraded in this assay and was replaced by $\mathrm{H} 2 \mathrm{~A}$ (previously found to similarly bind $\mathrm{I} \mathrm{KB} \alpha$ ). Chromatography analysis demonstrated that both $\mathrm{I} \mathrm{KBa}$ and $\mathrm{H} 2 \mathrm{~A}$ eluted at fraction 15-17 when run together, whereas IKBa or H2A alone eluted at fractions 29-30 and 18-20, respectively. This shift strongly suggested the existence of stable complexes that were composed of equimolar amounts of $\mathrm{I} \mathrm{KBa}$ and $\mathrm{H} 2 \mathrm{~A}$ proteins as determined by Coomassie Blue staining of the eluted fractions (Figure S1B). Then, we performed in vitro phosphorylation of $I \kappa B \alpha$ and SUMOylated I $\mathrm{KB} \alpha$ (Figure $\mathrm{S} 1 \mathrm{C}$ ) and tested the capacity of different $\mathrm{I} \mathrm{KB} \alpha$ species to bind to reconstituted nucleosome core particles (NCP) (instead of individual histones). We observed a significantly higher capacity of in vitro phosphorylated IkBa to 
form stable NCP-IkBa complexes compared with non-phosphorylated IKBa (Figure 1A). Of note that band retardation imposed by $\mathrm{p}-\mathrm{I} \mathrm{kB} \alpha$ and $\mathrm{pS}$-ІкBa was not significantly different likely due to loss of the SUMO chain during the experimental procedure. As an additional control, NCP-IkBa complexes were prevented or displaced by the addition of anti-IKBa in the binding reaction (Figure 1B).

Our results indicate that amino acids 1-200 of IKBa are required for $\mathrm{H} 4$ binding, which is independent of electrostatic forces and favored by $\mathrm{I} \mathrm{KB} \alpha$ phosphorylation.

\section{Preferential association of IKBa with acetylated histone $\mathrm{H} 4$ in vivo.}

We previously demonstrated that $\mathrm{pS}-\mathrm{IKBa}_{\mathrm{K}}$ binds the $\mathrm{N}$-terminal tail of histones $\mathrm{H} 2 \mathrm{~A}$ and $\mathrm{H} 4$ and identified acetylated $\mathrm{K} 12$ and $\mathrm{K} 16$ of $\mathrm{H} 4$ as preferential motifs for pS-IkBa binding in vitro (Mulero et al., 2013). To further investigate pS-IkBa binding specificity, we generated biotinylated peptides of the $\mathrm{N}$-terminal $\mathrm{H} 4$ sequence (aa1-23) including specific PTM combinations and used them to pulldown (PD) IkBa from cell extracts (Figure 2A). Both pS-IKBa ( $\approx 60 \mathrm{kDa})$ and non-SUMOylated $\mathrm{p}$-IKBa $(\approx 37 \mathrm{kDa})$ bands were consistently detected in the precipitates from non-modified $\mathrm{H} 4$ peptide, single K12Ac, K20Ac and double $\mathrm{K} 12,16 \mathrm{Ac}$ peptides. In contrast, mutation of $\mathrm{K}$ residues to $\mathrm{A}$, acetylation (Ac) of all four $\mathrm{K}$ residues $(\mathrm{K} 5, \mathrm{~K} 8, \mathrm{~K} 12$ and $\mathrm{K} 16)$ or single $\mathrm{K} 5 \mathrm{Ac}, \mathrm{K} 8 \mathrm{Ac}$ significantly reduced $\mathrm{I} \mathrm{KBa}$ binding to histone $\mathrm{H} 4$. Comparable binding inhibition was detected in peptides containing methylated K12 and K20 (Figures 2B). Binding affinity was confirmed in PD assays using GST-SUMO-IKBa as bait and serial dilutions of histone-enriched cell extracts (see methods) with the highest signal corresponding to the H4K16Ac and H4K20Ac marks and the lowest to H4K20me2,3 (Figures 2C). These results indicate that hyperacetylation or methylation of $\mathrm{K}$ residues reduce $\mathrm{I} \mathrm{KB} \alpha$ to histone $\mathrm{H} 4$ binding, whereas $\mathrm{H} 12, \mathrm{~K} 16$ and $\mathrm{K} 20$ acetylated histone binds to IKBa similar to the non-acetylated histone.

To study whether $\mathrm{H} 4$ acetylation favors IKBa binding to chromatin in vivo, we performed chromatin immunoprecipitation (ChIP) assay from HCT-116 colorectal cancer cells using the antibody against IkBa (IKBa, sc-307) and 2 antibodies against H4KAc (pan-H4KAc, Abcam ab177790 and H4K12ac, Active Motif 61527). Analysis of data demonstrated significant enrichment of IKBa 
peaks in acetylated chromatin regions $(p<0.01)$ compared with random distribution of peaks from both precipitations (Figure 2D). Moreover, we detected higher accumulation of H4KAc around the TSS of IKBa-bound genes compared with non-selected gene promoters (labelled as All genes) (Figure 2E, upper panels) as well as a significant overlap between IKBa and H4KAc peaks at specific genomic loci (Figure 2E, lower panels).

These results indicate that IKBa similarly binds acetylated histone $\mathrm{H} 4$ in vitro, which is precluded by $\mathrm{K}$ methylation, and preferentially binds acetylated $\mathrm{H} 4$ in vivo.

\section{Acetylated H4 species are restricted to stem cell compartments and lost in} differentiated cells associated to histone $\mathrm{N}$-tail cleavage.

Previous studies from our group demonstrated that nuclear pS-IKBa is localized in the stem cell compartments of skin and intestine (Marruecos et al., 2020; Mulero et al., 2013). Our results suggest that $\mathrm{pS}-\mathrm{IKB}_{\mathrm{K}}$ preferentially bind acetylated histone $\mathrm{H} 4$ in vivo (see Figures $2 \mathrm{D}$ and $2 \mathrm{E}$ ). Thus, we studied the possibility that nuclear $І \mathrm{~KB} \alpha$ was restricted to areas containing specific H4KAc marks. Different antibodies against acetylated histone $\mathrm{H} 4$ labeled cells localized in the intestinal crypt compartment colocalizing with $\mathrm{p}-\mathrm{I} \mathrm{kB \alpha}$ (Figure $3 \mathrm{~A}$ ), and including the canonical Lgr5+ ISCs (Figure 3B). Similarly, H4K12Ac was primarily detected in the keratinocytes of the basal layer of skin and the hair follicles, where progenitors and stem cells reside (Figure S2A). In contrast, H4K20me2,3, which showed the lower affinity for IKBa binding (see Figure 1AC), was exclusively present in differentiated cells of the intestinal villi and skin (Figure 3A and S2A). The few intestinal crypt cells that contained H4K20me2,3 mark were identified as terminally differentiated Paneth cells based on their morphology and localization (Figure $3 \mathrm{~A}$ and $3 \mathrm{~B}$ ). Compartmentalization of H4KAc and H4K20me marks was progressively reached during embryonic development (Figure S2B), which parallels the progressive restriction of nuclear IKBa distribution in the developing intestinal tissue (Marruecos et al., 2020).

Specific distribution of acetylated histone $\mathrm{H} 4$ restricted to the intestinal crypts was confirmed by western blot of crypts and villus-enriched fractions (Figure 3C). Remarkably, WB analysis of total histone H4, H4K2Ome2,3 and H4K2OKAc revealed the presence of a low molecular weight (LMW) band (red arrowheads 
in Figure 3C) specifically in the villus-enriched fractions. This result was confirmed in independent villus- and crypt-enriched extracts obtained from several mice (Figure 3D). The fact that the LMW band that was not recognized by the H4K5, K8, K12 and K16Ac antibodies (see Figure 3C) strongly suggested that the cleavage site of $\mathrm{H} 4$ mapped between $\mathrm{K} 16$ and $\mathrm{K} 20$ residues comprising the sequence KRHRK. Using a transgenic mouse line carrying mCherry fused to $\mathrm{H} 4$ (see methods), we confirmed that histone cleavage occurs in the intestinal villi in vivo, and involved the $\mathrm{N}$-terminal tail of histone $\mathrm{H} 4$ leading to the release of mCherry from the $\mathrm{H} 4$ protein (Figure $3 \mathrm{E}$ ). Comparable results were obtained by transfection of this construct in HCT-116 CRC cells (Figure 3F). PD experiments using chromatin extracts from intestinal villus demonstrated that $\mathrm{IKBa}$ specifically bound full-length histone $\mathrm{H} 4$ but failed to associate with truncated histone $\mathrm{H} 4$ lacking the $\mathrm{N}$-terminal tail (Figure 3G).

Our results indicated that intestinal cell differentiation correlates with $\mathrm{N}$-terminal truncation of histone $\mathrm{H} 4$ resulting in a cleaved histone $\mathrm{H} 4$ form that is unable to bind IKBa.

Cleavage of the $\mathrm{N}$-terminal tail of $\mathrm{H} 4$ is mediated by chymotrypsin an trypsin activity present in the intestinal villus.

To address the possibility that histone $\mathrm{H} 4$ cleavage was due to the activity of a protease specifically contained in the differentiated intestinal cells, we incubated crypt-derived chromatin extracts (containing intact histone $\mathrm{H} 4$ ) with soluble lysates from either villus-derived or crypt-derived cells. Cleavage of histone H4 was specifically induced by incubation with villus-derived lysates (Figure 4A) further indicating that one or more proteases present and active in the differentiated cells induce histone $\mathrm{H} 4$ cleavage. Then, we obtained villus- and crypts-enriched cell fractions (by cell sorting based on EPHB2 levels), purified the RNA and performed RNA-seq analysis. We identified several proteases that were specifically expressed in the villus-derived RNA (Figure 4B). Bioinformatic analysis using the PeptideCutter-ExPASy (Wilkins et al., 1999) and PROSPER (Song et al., 2012) tools identified the serine proteases trypsin and chymotrypsin $\mathrm{C}$ as the most likely enzymes capable to cleave histone $\mathrm{H} 4$ in the region involving residues $\mathrm{K} 16$ to $\mathrm{K} 20$, which we have experimentally identified as the sites for cleavage. By point mutation of specific $\mathrm{H} 4$ residues in mCherry- 
H4 fusion protein, we recognized amino acids 17-19 as essential for $\mathrm{H} 4$ cleavage (Figure 4C), which is consistent with trypsin or chymotrypsin as responsible for this activity.

To further test whether trypsin or chymotrypsin execute histone $\mathrm{H} 4$ cleavage, we treated mCherry-H4 expressing HCT-116 cells with the specific inhibitors of trypsin-like proteases TLCK and $A_{d a A h x} L_{3} V S$ for 16hours. WB analysis indicated that TLCK (Figure 4D) or $\mathrm{AdaAhx}_{3} \mathrm{~L}_{3} \mathrm{VS}$ (Figure 4E) imposed a dosedependent inhibition of mCherry-H4 (Figures 4D and 4E) and endogenous H4 cleavage (Figure 4F). Moreover, treatment with protease inhibitors was associated with increased chromatin retention of $\mathrm{p}-\mathrm{IKBa}(\approx 37 \mathrm{kDa})$ and $\mathrm{pS}-\mathrm{IKBa}_{\mathrm{K}}$ ( $\approx 60 \mathrm{kDa})$ as determined by WB of chromatin extracts (Figure 4F).

It is established that trypsin and trypsin-like proteases digest substrates containing unmodified $\mathrm{K}$ residues but this activity can be affected by $\mathrm{K}$ acetylation due to both steric effects and loss of the positive charge (Huang et al., 2015). We used different histone H4 peptides (aa1-23) to determine whether protease activity from villus-derived extracts was modified by specific $\mathrm{K}$ modifications. Our data indicated that villus extracts (but not with crypt-derived extracts) induced the degradation of histone $\mathrm{H} 4$ peptides with the only exception of the $\mathrm{K}$ to $\mathrm{A}$ mutant and the peptide with all $\mathrm{K}$ residues acetylated (K5,8,12,16Ac) (Figure 4G and 4H).

Together these results indicate that trypsin and chymotrypsin can induce histone $\mathrm{H} 4$ cleavage, and suggest that these proteases are responsible for physiologic $\mathrm{N}$-terminal $\mathrm{H} 4$ truncation that occurs during intestinal differentiation.

Functional impact of $\mathrm{IKB} \alpha$ chromatin binding dynamics in cell differentiation.

IKBa deficiency results in altered stem cell maturation and defective intestinal and skin differentiation in mice (Marruecos et al., 2020; Mulero et al., 2013). To further investigate the impact of $\mathrm{IKB} \alpha$ association to chromatin in intestinal differentiation, we used the HT29 CRC cells that differentiate into the goblet cell lineage at confluence. We found that IKBa deletion (KO) by CRISP-Cas9 precluded goblet cell differentiation of human HT29 CRC cells at 7 days of post- 
confluence as determined by qPCR (Figure 5A) and WB analysis (Figure 5B) of the terminal differentiation markers MUC5AC and SPDEF.

We then tested whether inhibition of histone cleavage, which favors pS-IKBa chromatin retention, affected HT29 differentiation. Treatment with the trypsinlike inhibitors TLCK or $\mathrm{AdaAhx}_{3} \mathrm{~L}_{3} \mathrm{VS}$ (Figure 5C and 5D) or knocking down trypsin or chymotrypsin with different shRNA (Figure 5E, 5F and S3) both precluded goblet cell differentiation of HT29 cells, comparable to the effects imposed by IKBa deletion. These results suggest that histone cleavage, which favors dissociation of $\mathrm{IKBa}$ from the chromatin, is required for intestinal cell differentiation.

Together our results support a model in which dynamic binding/dissociation of IkBa to/from chromatin regulates specific gene transcription, which is essential for stem cell maturation and subsequent progression towards tissue-specific mature lineages (Brena et al., 2020; Marruecos et al., 2020; Mulero et al., 2013 and this work). Thus, in the absence of chromatin-bound IKBa or in case of irreversible IkBa chromatin binding (i.e. after trypsin or chymotrypsin inhibition), tissue stem cells and/or progenitors are retained into an immature state and fail to express differentiation markers such as epidermal Filaggrin and Keratin 10 (Mulero et al., 2013) or intestinal Muc2, Lyz1 (Marruecos et al., 2020) and Muc5 (this work) (see model in Figure 5G).

\section{Discussion}

We have previously demonstrated the existence of moonlighting functions for the essential NF-KB inhibitor IKBa as modulator of PRC2 activity at specific genomic loci. Now, we show that nuclear IkBa preferentially binds acetylated $\mathrm{H} 4$ species that are restricted to the stem cell compartment of the intestine and skin where nuclear $\mathrm{p}$-IkBa is also localized. Loss of acetylated histone $\mathrm{H} 4$ in the differentiated compartments is likely due to the cleavage of its $\mathrm{N}$-terminal tail (the region substrate of histone acetylation) by the action of specific proteases. We have identified trypsin and chymotrypsin as the most likely proteases involved in histone $\mathrm{H} 4$ cleavage in vivo. Moreover, different modifications at $\mathrm{K}$ residues affect protease activity on histone $\mathrm{H} 4$, as is the case of the $\mathrm{H} 4 \mathrm{~K} 5,8,12,16 \mathrm{~A}$ mutation or the hyperacetylated $\mathrm{H} 4 \mathrm{~K} 5,8,12,16 \mathrm{Ac}$, as expected. 
This result, together with the observation that crypt-derived histone $\mathrm{H} 4$ is cleaved after incubation with soluble villus lysates, indicate that histone $\mathrm{H} 4$ in the crypts is not hyperacetylated but different H4Ac species (i.e. H4K5Ac, H4K8Ac, H4K12Ac) may coexist in this cellular compartment.

$\mathrm{N}$-terminal cleavage of histones, mainly $\mathrm{H} 3$, was previously reported in other systems associated with organism development and cell differentiation (Duncan et al., 2008; Kim et al., 2016; Melo et al., 2017; Vossaert et al., 2014). We propose that $\mathrm{N}$-terminal loss at specific histones might represent a general but specific mechanism of gene regulation during development and tissue differentiation imposed by levels and activity of proteases recognizing specific histones and histone codes. IKBa dissociation from particular gene promoters (i.e. during cell differentiation) may be linked to local histone cleavage events that could be, in turn, controlled by acetylation or other PTMs. This dynamics of IKBa binding and dissociation would then trigger a switch in the repertoire of activators and repressors bound as specific gene promoters leading to a whole transcriptional response, which we will further investigate.

Because of the significant impact of nuclear IKBa in cell differentiation and stem cell maturation, and our previous data obtained in squamous cell carcinoma (Mulero et al., 2013), we speculate that IKBa chromatin binding and histone cleavage could similarly play a relevant contribution to tumorigenesis and tumor metastasis, which mainly depend on the stem cell-like capacity of tumor cells. Our prediction is that $\mathrm{I} \mathrm{KBa}$ may represent a unique cellular tool for the integration of pro-inflammatory signals provided by the tumor stroma into a transcriptional program that impacts in cellular stemness. This IkBa function that facilitates the maintenance of stem cell homeostasis in response to inflammation or damage, would also execute pro-tumorigenic and prometastatic activities linked to inflammatory tumor microenvironments thus counteracting the positive effect of the immune system.

In brief, we have identified a previously unanticipated linked between histone cleavage and IKBa function during cell differentiation, which could have a relevant impact in the field of tissue regeneration, stemness and tumor metastasis. 


\section{MATERIALS AND METHODS}

\section{Animal Studies}

WT mice and Lgr5 ${ }^{\text {GFP-CreERT }}$ mice were from The Jackson Laboratories. In all procedures, animals were kept under pathogen-free conditions, and animal work was conducted according to the guidelines from the Animal Care Committee at the Generalitat de Catalunya. The Committee for Animal Experimentation at the Institute of Biomedical Research of Bellvitge (Barcelona) approved these studies.

Transgenic mice carrying Cherry-histone $\mathrm{H} 4$ were generated by transduction of a piggyback construct to ES cells.

\section{Cell lines and reagents}

All cells were grown in Dulbecco's modified Eagle's medium (DMEM) [Invitrogen] supplemented with $10 \%$ fetal bovine serum (FBS) [Biological Industries]. Cells were grown in an incubator at $37^{\circ} \mathrm{C}$ and $5 \% \mathrm{CO}$. Cells used in these studies were HEK-293T [ATCC Ref. CRL-3216], HT29 [ATCC Ref. HTB-38D] and HCT-116 [ATCC Ref. CCL-247]. Reagents used are the following: TLCK (Tosyl-L-lysyl-chloromethane hydrochloride) [Abcam ab144542] and AdaAhx3L3VS [Sigma-Aldrich 114802]. HT29 ІкBa KO cells were generated by CRISPR-Cas9 using guides targeting exon 1.

\section{Villus/crypt-enriched fractionation}

Intestine of WT mice was extracted. Villus was separated from crypts mechanically, as described previously (Marruecos et al., 2020). Then, crypts were purified by mechanical disaggregation and filtration in a $70 \mu \mathrm{m}$ cell strainer.

\section{Cell transfection}

We used Polyethylenimine (PEI) [Polysciences Inc. Ref. 23996] as a carrier vector following standard methods. In brief, we diluted $4 \mu \mathrm{PEI}$ per $\mu \mathrm{g}$ of DNA in serum-free DMEM and incubated $5 \mathrm{~min}$ at room temperature. Then, we added the DNA and incubated the mix 20min at RT. Finally, we incorporated the PEI/DNA solution to the cell cultures. 


\section{Pull down and peptide immunoprecipitation (IP) assays}

PD assays were performed as previously described (Espinosa et al., 2003). Briefly, GST fusion proteins were incubated with lysates for $45 \mathrm{~min}$ in a rotary shaker at $4^{\circ} \mathrm{C}$. When indicated, nuclear extracts were boiled at $98^{\circ} \mathrm{C}$ for $5 \mathrm{~min}$ in the presence of $1 \%$ SDS to disassemble pre-existing protein complexes and then neutralized in $1 \%$ Triton $\mathrm{X}-100$. Precipitates were resolved in SDS-PAGE and analyzed by IB. For peptide IP, histone H4 peptides [Synpeptide CO LTD ] were synthesized as biotinylated $\mathrm{N}$-terminal and $\mathrm{C}$-terminal amides. Peptides were incubated overnight at $4^{\circ} \mathrm{C}$ with the indicated cell extracts and precipitated with streptavidin-sepharose beads for $45 \mathrm{~min}$.

\section{Cell fractionation and Western Blot (WB)}

For soluble and chromatin separations, cells were lysed 1mM EDTA, 0.1mM Na-orthovanadate (Na3VO4), 0.5\% Triton X-100, 20mM $\beta$ - glycerol-phosphate, $0.2 \mathrm{mM}$ PMSF, protease inhibitor cocktail, in PBS for $20 \mathrm{~min}$ on ice and centrifuged at 13,000 rpm. Supernatants were recovered as the soluble fraction, and the pellets were lysed in Laemmli buffer (1x SDS-PAGE buffer plus $\beta$ mercaptoethanol (BME) [Sigma, Ref. M-3148]) or in 1\%SDS PBS, sonicated and treated with 1\% TritonX-100. For histone enriched fractions, cells were lysed in 10mM HEPES pH7.9, 1.5mM MgCl2, 10mM KCl, 0.5mM DTT, 1.5mM PMSF, $100 \mathrm{mM}$ sodium butyrate, protease inhibitor cocktail and $0.2 \mathrm{mM} \mathrm{H}_{2} \mathrm{SO}_{4}$ for $30 \mathrm{~min}$ on ice and centrifuged at $10080 \mathrm{~g}$. Then supernatants were dialyzed against PBS. Lysates were analyzed by Western blotting using standard SDSpolyacrylamide gel electrophoresis (SDS-PAGE) techniques. In brief, protein samples were boiled in Laemmli buffer, run in polyacrylamide gels, and transferred onto polyvinylidene-difluoride (PVDF) membranes [Millipore Ref. IPVH00010]. Membranes were incubated overnight at $4^{\circ} \mathrm{C}$ with the appropriate primary antibodies, extensively washed and then incubated with specific secondary horseradish peroxidase-linked antibodies from Dako [Ref. P0260 and P0448]. Peroxidase activity was visualized using the enhanced chemiluminescence reagent [Biological Industries Ref. 20-500-120] and autoradiography films [GE Healthcare Ref. 28906835]. Gels were stained with Coomassie (Brilliant Blue G-250 [Sigma Ref.6104-58-1]. 


\section{Antibodies used}

\begin{tabular}{|c|c|c|c|c|}
\hline Antibody & Company & Reference & Specie & Dilution \\
\hline Histone H3 & Abcam & $a b 1791$ & Rabbit & $1: 5000$ \\
\hline Histone H4 & Abcam & $a b 10158$ & Rabbit & $1: 1000$ \\
\hline Histone $\mathrm{H} 2 \mathrm{~A}$ & Abcam & ab18258 & Rabbit & $1: 1000$ \\
\hline H4K12ac & Active Motif & 61527 & Mouse & $1: 1000$ \\
\hline H4K16ac & Active Motif & 61529 & Mouse & $1: 1000$ \\
\hline H4K20me2,3 & Abcam & $a b 78517$ & Mouse & $1: 1000$ \\
\hline H4K5ac & Active Motif & 39169 & Rabbit & $1: 1000$ \\
\hline H4K8ac & Active Motif & 61103 & Rabbit & $1: 1000$ \\
\hline H4K20ac & Active Motif & 61531 & Mouse & $1: 1000$ \\
\hline $\mathrm{IKB} \alpha$ & Abcam & ab32518 & Rabbit & $1: 1000$ \\
\hline$P-I K B \alpha$ & Cell Signalling & $\# 9246$ & Mouse & $1: 1000$ \\
\hline Tubulin- $\alpha$ (clone B-5-1-2) & Sigma Aldrich & T6074 & Mouse & $1: 10000$ \\
\hline Lamin B (C-20) & Santa Cruz & sc-6216 & Goat & $1: 1000$ \\
\hline \multicolumn{5}{|l|}{ His } \\
\hline Cherry & Abcam & ab167453 & Rabbit & $1: 1000$ \\
\hline \multicolumn{5}{|l|}{ Biotin } \\
\hline \multicolumn{5}{|l|}{ Muc5 } \\
\hline $\begin{array}{l}\text { Polyclonal Goat anti-Rabbit } \\
\text { Immunoglobulins/HRP }\end{array}$ & Dako & P0448 & $\begin{array}{l}\text { Goat } \\
\text { anti- } \\
\text { Rabbit }\end{array}$ & $1: 2000$ \\
\hline $\begin{array}{l}\text { Polyclonal Rabbit anti-Mouse } \\
\text { Immunoglobulins/HRP }\end{array}$ & Dako & P0260 & $\begin{array}{l}\text { Rabbit } \\
\text { anti- } \\
\text { Mouse }\end{array}$ & $1: 2000$ \\
\hline $\begin{array}{l}\text { Polyclonal Rabbit anti-Goat } \\
\text { Immunoglobulins/HRP }\end{array}$ & Dako & P0449 & $\begin{array}{l}\text { Rabbit } \\
\text { anti-goat }\end{array}$ & $1: 2000$ \\
\hline
\end{tabular}

\section{Immunofluorescence (IF) analysis}

Tissues were fixed in $4 \%$ formaldehyde overnight at room temperature and embedded in paraffin. $4 \mu \mathrm{m}$ paraffin embedded sections were first deparaffinized in xylene. IHC was performed following standard techniques with EDTA- or citrate-based antigen retrieval and developed with the Envision+ System HRP Labelled Polymer anti-Rabbit [Dako Ref. K4003] or anti-Mouse [Dako Ref. K4001] and developed with TSA ${ }^{\mathrm{TM}}$ Plus Cyanine 3/ Fluorescein System [PerkinElmer Ref. NEL753001KT] and mounted in ProLong ${ }^{\text {TM }}$ Diamond 
Antifade Mountant plus DAPI [Thermo Scientific Ref. P36971]. Images were taken in an SP5 upright confocal microscope (Leica).

\section{Size exclusion chromatography}

GST-H2A or His-IKBa 1-200 proteins were expressed in BL21 bacteria and lysed as explained above. Then, proteins were purified using glutathioneSepharose [Amersham Biosciences] or Nickel-NTA [Qiagen] resins, respectively. After elution, proteins were buffered exchanged using desalting columns [GE Healthcare] to a buffer containing $25 \mathrm{mM}$ Tris $\mathrm{pH} 7.4,150 \mathrm{mM}$ $\mathrm{NaCl}, 0.2 \mathrm{mM}$ EDTA pH 8.0, $1 \mathrm{mM}$ PMSF and $1 \mathrm{mM}$ DTT. Then, individual proteins (GST-H2A and His-IKBa 1-200) or a mix of both proteins at a ratio of $1: 1$ incubated at room temperature for $1 \mathrm{hr}$ to form complexes prior size exclusion chromatography were analyzed. $150 \mu \mathrm{l}$ of each sample was loaded onto an analytical Superdex SD200 10/300 column [GE Healthcare] preequilibrated with the sample buffer and resolved at a flow rate of $0.5 \mathrm{ml} / \mathrm{min}$ on an AKTA Purifier [GE Healthcare] automated liquid chromatography system. 0.5 $\mathrm{ml}$ size fractions were collected and an equal volume aliquot of each fraction was analyzed by SDS-PAGE followed by Coomassie Blue staining.

\section{Recombinant histone octamer formation}

pET11a-H2A, pET11a-H2B and pET11a-H3-H4 plasmids were a kind gift from Dr. James Kadonaga, UCSD. The original pET11a-H2B plasmid was mutated to pET11a-lle-H2B (inserting an Isoleucine residue before the H2B sequence) to increase its protein yield. All histones were expressed in Escherichia coliBL21(DE3) by growing cells to A600 0.5-0.6 followed by induction with $0.2 \mathrm{mM}$ isopropyl $\beta$-D-1-thiogalactopyranoside (IPTG) for $3 \mathrm{~h}$ at $37^{\circ} \mathrm{C}$.Cells were pelleted by centrifugation at $3000 \mathrm{rpm}$ for $20 \mathrm{~min}$ at $4^{\circ} \mathrm{C}$ and washed once with phosphate-buffered saline $\left(4 \mathrm{mM} \mathrm{Na}_{2} \mathrm{HPO}_{4}, 1 \mathrm{mM} \mathrm{K \textrm {K } _ { 2 }} \mathrm{PO}_{4}, 137 \mathrm{mM} \mathrm{NaCl}\right.$ and $3 \mathrm{mM} \mathrm{KCl})(100 \mathrm{ml} /$ liter bacterial cell culture). The H2A-H2B dimers and H3-H4 tetramers were purified following the detailed protocol previously published (Levenstein and Kadonaga, 2002). 
Histone octamer formation was performed following the protocols from Dyer et al (Dyer et al., 2003) with some modifications. Briefly, histones molar ratio was quantified using A280 (Nanodrop) and applying an extinction coefficient for $\mathrm{H} 2 \mathrm{~A} / \mathrm{H} 2 \mathrm{~B}, 10.240 \mathrm{~cm}^{-1} \mathrm{M}^{-1}$ and for $\mathrm{H} 3 / \mathrm{H} 4,9080 \mathrm{~cm}^{-1} \mathrm{M}^{-1}$, respectively. Mixed histones were unfolded with Unfolding Buffer $(20 \mathrm{mM}$ Tris- $\mathrm{HCl} \mathrm{pH} 7.5,10 \mathrm{mM}$ DTT and $7 \mathrm{mM}$ guanidinium hydrochloride) for $2 \mathrm{~h}$ at $4^{\circ} \mathrm{C}$. Then, the sample was dialyzed against the Refolding Buffer (10mM Tris-HCl pH 7.5, $1 \mathrm{mM}$ EDTA, 5mM $\mathrm{BME}$ and $2 \mathrm{M} \mathrm{NaCl}$ ) at $4^{\circ} \mathrm{C}$ two times $3 \mathrm{hr}$ each and then $\mathrm{ON}$. The day after, the sample was concentrated using a Centriprep 30-kDa cutoff membrane concentrator unit [Millipore] at $4^{\circ} \mathrm{C}$ and injected in a gel filtration analytical Superdex SD200 column. Fractions containing the histone octamer were pooled and dialyzed against Refolding Buffer with $50 \%$ glycerol (10mM Tris$\mathrm{HCl} \mathrm{pH} 7.5,1 \mathrm{mM}$ EDTA, $5 \mathrm{mM}$ BME, $2 \mathrm{M} \mathrm{NaCl}$ and $50 \%$ (v/v) glycerol) at $4^{\circ} \mathrm{C}$ $\mathrm{ON}$. Histone octamers were aliquoted and stored at $-80 \mathrm{C}$.

\section{Nucleosome formation}

Original 601-DNA 12 copies plasmid was a kind gift from Dr. Karolyn Luger. Nucleosome core particles (NCP) were reconstituted following the classical salt gradient method. Briefly, we mixed 1ug of DNA with different volumes of histone octamers in a buffer containing $10 \mathrm{mM}$ Tris- $\mathrm{HCl} \mathrm{pH} 8.0,2 \mathrm{M} \mathrm{NaCl}$ and $1 \mathrm{mM}$ EDTA. Samples were dialyzed using a $3.5 \mathrm{kDa}$ cut-off Slide-A-Lyzer Mini dialysis device [Thermo Fischer Scientific]. We dialyzed the $\mathrm{NaCl}$ concentration from the initial $2 \mathrm{M}$ to $1.5 \mathrm{M}, 1 \mathrm{M}, 800 \mathrm{mM}, 600 \mathrm{mM}$ in the same buffer changing the dialysis every $3 \mathrm{hr}$ at $4^{\circ} \mathrm{C}$. Finally, we left the dialysis going overnight at $2.5 \mathrm{mM} \mathrm{NaCl}$. The day after we changed the buffer one more time $3 \mathrm{hr}$ at $4^{\circ} \mathrm{C}$ in presence of $2.5 \mathrm{mM} \mathrm{NaCl}$. Successful NCP reconstitution was confirmed by running a native electrophoretic mobility shift assay (EMSA) loading $10 \mathrm{ng}$ of NCPs in a $4 \%$ native acrylamide gel $(19: 1)$ in the cold room. Before loading, samples were mixed with $10 \%(\mathrm{v} / \mathrm{v})$ glycerol in absence of bromophenol blue to preserve the integrity of the NCPs. 
Purified full length His-IKBa protein was incubated with PKA in the kinase buffer 20mM HEPES pH 7.9, 150mM NaCl, 10mM MgCl2, 10mM NaF, 0.2mM sodium orthovanadate and $20 \mu \mathrm{M}$ ATP for 30 minutes at $30^{\circ} \mathrm{C}$. Immediately after, NCP were incubated with increasing concentrations of phosphorylated IKBa $\left(p-I_{\kappa} B \alpha\right)$ for $1 \mathrm{hr}$ at $4^{\circ} \mathrm{C}$. $\mathrm{p}$-IKBa was obtained by incubation of recombinant $\mathrm{IkB \alpha}$ with active IKKB in the presence of ATP. When indicated, anti-IKBa antibody was added to the mix to block the NCP-IkBa interaction. After, NCP-IkBa complexes were run in a $4 \%$ native acrylamide gel (19:1) in the cold room. Gels were stained using GelRed [Biotium] for $30 \mathrm{~min}$ and destained using TBE 0.5X 3 times for $10 \mathrm{~min}$ in the cold room. Gels were imaged using a GelDoc system [Bio-Rad].

\section{Radiolabeled electrophoretic mobility assay}

601-DNA was radiolabeled with ${ }^{32} \mathrm{P}$ using T4-polynucleotide kinase and $\left[\mathrm{Y}^{-}{ }^{32} \mathrm{P}\right]$ ATP for $1 \mathrm{hr}$ at $37^{\circ} \mathrm{C}$ and then incubated with the histone octamer in presence of $2 \mathrm{M} \mathrm{NaCl}$. Here, NCP formation was achieved by sequential dilution instead of dialysis as described above. Radiolabelled NCPs were incubated with the proteins under study for $20 \mathrm{~min}$ at room temperature in binding buffer $10 \mathrm{mM}$ Tris- $\mathrm{HCl}(\mathrm{pH} 7.5), 50 \mathrm{mM} \mathrm{NaCl}, 10 \%$ (v/v) glycerol, 1\% (v/v) NP-40, $1 \mathrm{mM}$ EDTA, and $0.1 \mathrm{mg} / \mathrm{mL}$ PolydldC. Samples were run in TGE buffer $(24.8 \mathrm{mM}$ Tris base, $190 \mathrm{mM}$ glycine, and $1 \mathrm{mM}$ EDTA) at $200 \mathrm{~V}$ for $1 \mathrm{hr}$, and the gel was dried. Protein complexes were analyzed by native electrophoresis on a $4 \%(\mathrm{w} / \mathrm{v})$ native acrylamide gel.

\section{Knock down assays}

MISSION shRNA for trypsin and chymotrypsin plus lentiviral plasmids were transfected in HEK293T cells. One day after transfection, media was refreshed. Virus was collected 24 hours later and then concentrated using Ultracentrifuge Optima $^{\text {TM }}$ XPN-100 - IVD (Biosafe) [Beckman Coulter]. Cells were infected and selected with puromycin. 


\section{Chromatin Immunoprecipitation (ChIP) and ChIP-sequencing analysis}

Human colon cell lines were subjected to chromatin immunoprecipitation (ChIP) as previously described (Aguilera et al., 2004; Mulero et al., 2013). Briefly, formaldehyde crosslinked cell extracts were sonicated, and chromatin fractions were incubated for 16 hours with anti-IкBa [abcam ab32518], anti- P-ІкBa [Cell Signaling \#9246], anti-Acetylated H4 [Abcam ab177790] and anti-H4K12ac [Active Motif 61527] antibodies in RIPA buffer and then precipitated with protein A/G-sepharose [GE Healthcare, Refs. 17-0618-01 and 17-0780-01]. Crosslinkage was reversed and 6-10 ng of precipitated chromatin was directly sequenced in the genomics facility of Parc de Recerca Biomèdica de Barcelona (PRBB) using Illumina HiSeq platform.

Raw single-end 50-bp sequences were filtered by their quality $(Q>30)$ and length (length > 20-bp) with the Trim Galore software (available at http://www.bioinformatics.babraham.ac.uk/projects/download.html\#trim_galore). Filtered sequences were aligned against the reference genome ( $\mathrm{mm} 10$ release) with Bowtie2. MACS2 software was run first for each replicate, and then by combining all replicates, using unique alignments (q-value $<0.1)$. Broad peaks calling was set. Peak annotation was performed with ChIPseeker package and functional enrichment analysis with enrichR using the latest version of $\mathrm{GO}$ annotations. ChIP-sequencing data are submitted to GEO database.

\section{Cell sorting}

Villus and crypt cells were obtained after mechanical disaggregation and $40 \mu \mathrm{m}$ filtration. Cells were incubated with APC-EphB2 antibody [BD Pharmingen Ref. 564699] for 20min, stained with DAPI and the sorted in an Influx ${ }^{\mathrm{TM}}$ Sorter [BD Biosciences].

\section{qRT-PCR analysis}

Total RNA was extracted with the RNeasy Mini Kit [Qiagen Ref. 74004] and the RT-First Strand cDNA Synthesis Kit [GE Healthcare Life Sciences Ref. 279261-01], was used to produce cDNA. qRT-PCR was performed in LightCycler480 system using SYBR Green I Master Kit [Roche Ref. 04887352001]. The primers used are listed in the table below. 


\begin{tabular}{|l|l|l|l|}
\hline Target & Specie & Forward & Reverse \\
\hline MUC5AC & Human & CTGGTGCTGAAGAGGGTCAT & CAACCCCTCCTACTGCTACG \\
\hline SPDEF & Human & CTGTGGACAGAGCACCAATACC & GGTCGAGGCACAGTAGTGAATC \\
\hline
\end{tabular}

\section{RNA-sequencing experiments and data analysis}

We extracted total RNA using RNeasy Micro Kit [Qiagen Ref. 74004]. The RNA concentration and integrity were determined using Agilent Bioanalyser [Agilent Technologies]. Libraries were prepared at the Genomics unit of PRBB (Barcelona, Spain) using standard protocols and cDNA was sequenced using Illumina ${ }^{\circledR}$ HiSeq platform, obtaining 25 to 30 million 50bp single-end reads per sample. Adapter sequences were trimmed with Trim Galore. Sequences were filtered by quality $(Q>30)$ and length (>20 bp). Filtered reads were mapped against the latest release of the mouse reference genome (mm10) using default parameters of TopHat (v.2.1.1) (Kim et al., 2013) and expressed transcripts were then assembled. High quality alignments were fed to HTSeq (v.0.9.1) (Anders et al., 2015) to estimate the normalized counts of each expressed gene. Differentially expressed genes between different conditions were explored using DESeq2 R package (v.1.20.0) (Love et al., 2014). Plots were done in R. RNA-sequencing data are deposited at the GEO database with accession number GSE131187.

\section{Quantification and Statistical Analysis}

Statistical parameters, including number of events quantified, standard deviation, and statistical significance are reported in the figures and in the figure legends. Statistical analysis has been performed using GraphPad Prism6 software (GraphPad) and $\mathrm{p}<0.05$ is considered significant. Two-sided Student's t-test was used to compare differences between two groups. Each experiment shown in the manuscript has been repeated at least twice.

\section{Data availability}

RNA-Seq

data:

GEO

databaseGSE131187

https://www.ncbi.nlm.nih.gov/geo/query/acc.cgi?acc=GSE131187 
bioRxiv preprint doi: https://doi.org/10.1101/2021.02.15.431217; this version posted February 16, 2021. The copyright holder for this preprint (which was not certified by peer review) is the author/funder. All rights reserved. No reuse allowed without permission.

\section{ChIP-seq data has been submitted to GEO database.}




\section{Figures and Legends}

A

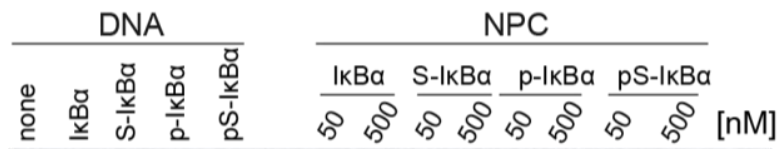

B
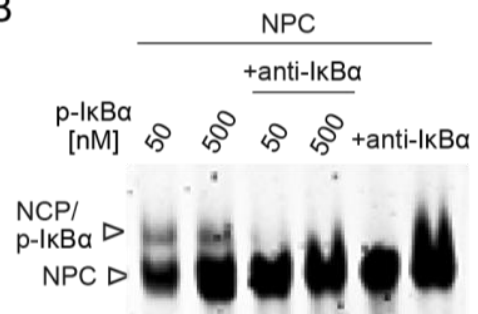

DNA D

$\mathrm{EtBr}$ (agarose gel)

EMSA (32p-ATP-labelled)

Figure 1. Specific interaction of nucleosome particles with phosphorylated IкBa (A) Electrophoretic analysis (under non-denaturing conditions) of the association between the indicated IKBa species association and reconstituted nucleosome core particles (NCP). (B) Electrophoretic analysis in agarose gels of in vitro generated $\mathrm{p}$ - $\mathrm{IkB \alpha}$ and reconstituted nucleosome in absence or presence of anti-IKBa antibodies.

A

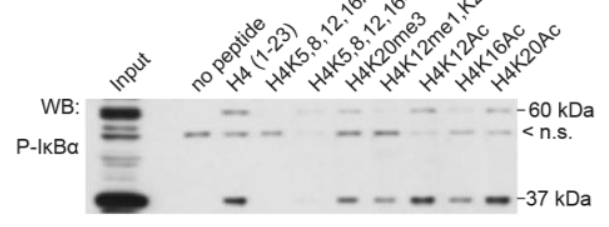

B
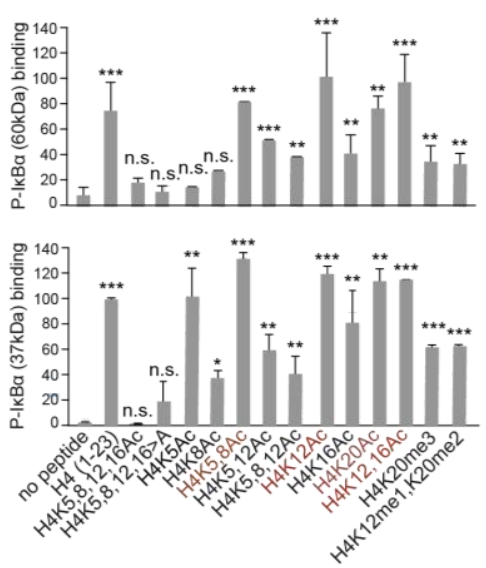

C

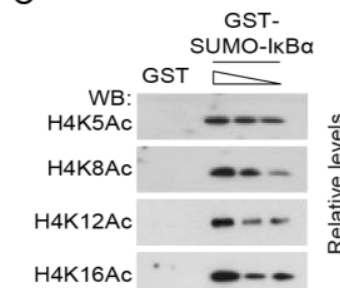

$-$

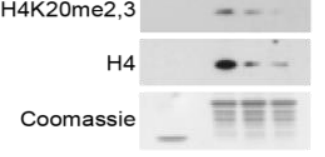

D

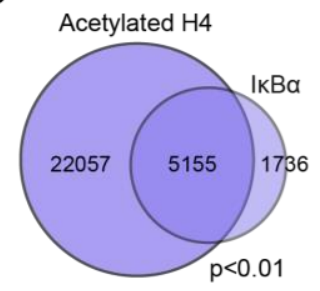

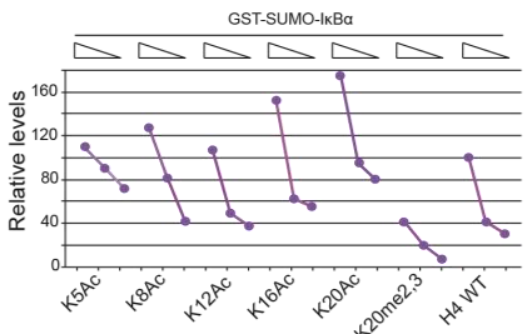

$\mathrm{E}$

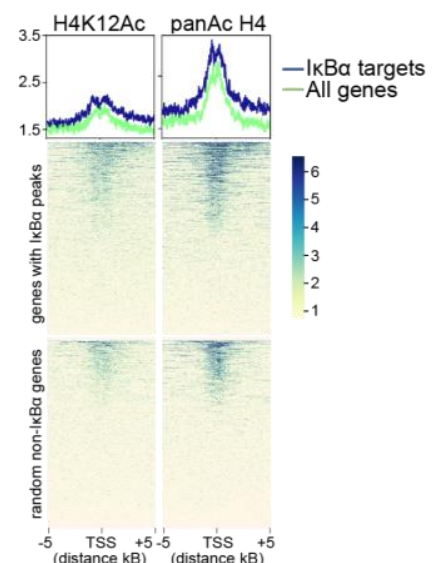

Figure 2. Preferential association of IKBa with $\mathrm{N}$-terminal acetylated histone H4. (A) PD experiment with biotinylated peptides of H4 (1-23aa) and total lysates of HCT-116 cells. (B) Quantification of the IKBa $60 \mathrm{kDa}$ band (upper panels) and the $37 \mathrm{kDa}$ band (lower panels) is shown as average and 
s.d. of three independent experiments. (C) PD experiments with GST-SUMO IKBa fusion protein and serial dilutions of histone-enriched HEK-293T lysates. Quantification of three independent replicates is shown. (D) Venn diagrams representing the overlap between $\mathrm{I} \mathrm{KB} \alpha$ and acetylated $\mathrm{H} 4$ peaks obtained in ChIP-seq experiments from HCT-116 cells. (E) Peak distribution of acetylated $\mathrm{H} 4$ and H4K12ac obtained in IKBa target genes and non-IKBa targets relative to the transcription start site (TSS). WB in A and $C$ are representative of three independent replicates performed. In $B, p$ values were derived from unpaired two-tailed $t$-test of triplicates, ${ }^{* *} p$-value $<0.001,{ }^{* *} p$-value $<0.01,{ }^{*} p$-value $<0.05$, n.s. no significant.

A
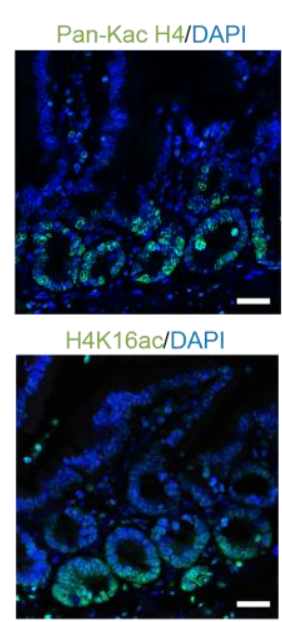

C

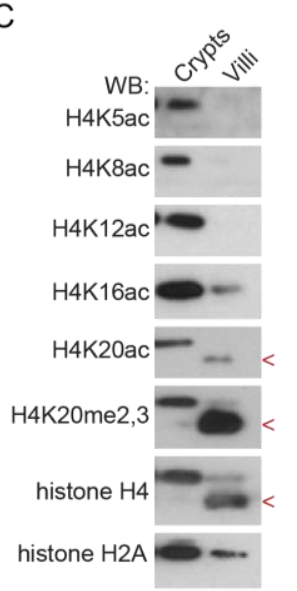

H4K5ac/DAPI

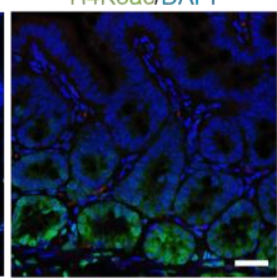

H4K20ac/DAPI

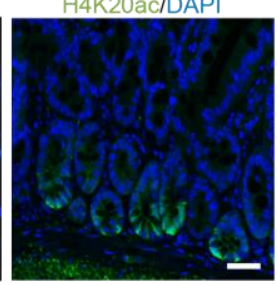

$\mathrm{D}$

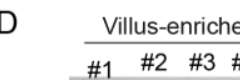

WB:

$\mathrm{H} 4$

E

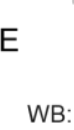

WB:
mCherry

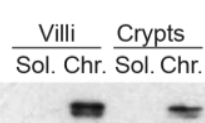

F

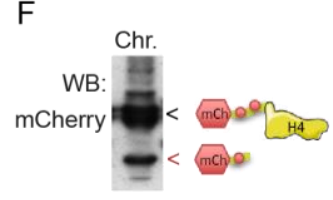

B

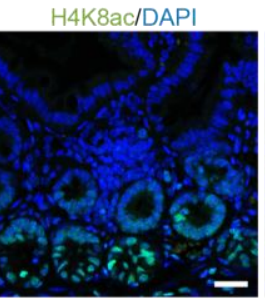

H4K12ac/DAPI

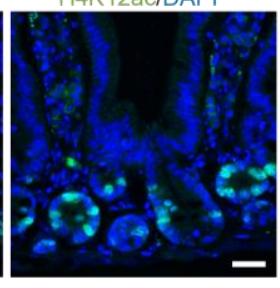

H4K12ac/p-|кBo/DAPI
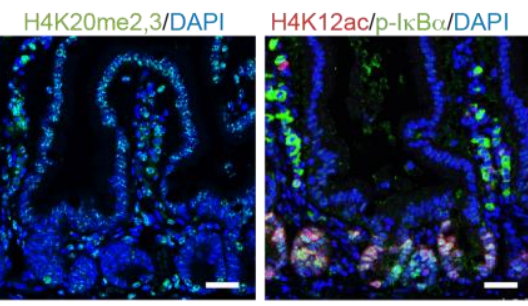

Lgr5-GFP mice


G

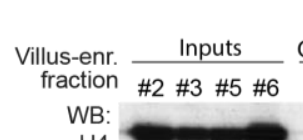

PD: $\quad$ PD:

GST GST-SUMO-IKBa

\#2 \#3 \#5 \#6

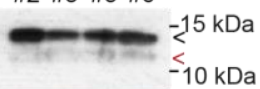

$\mathrm{H} 4$

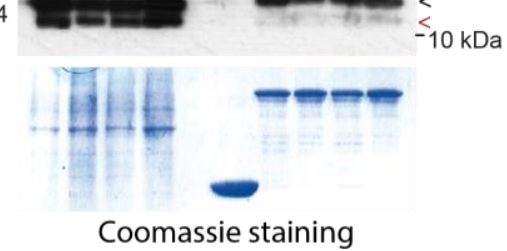

Figure 3. Stem cell compartments contain acetylated $\mathrm{H} 4$ species that are lost following histone cleavage. (A) Immunofluorescence (IF) analysis with the indicated antibodies in sections from murine small intestine of 2-month-old WT mice. (B) Double IF analysis with the indicated antibodies in sections from murine small intestine of 2-month-old Lgr5-GFP transgenic mice. (C) Western 
Blot analysis of chromatin extracts from isolated intestinal villus and crypt cells. (D) Western Blot analysis of chromatin extracts from isolated intestinal villus and crypt cells in several 2-month-old WT mice (each \# represents a mouse). (E) Western Blot analysis of soluble (Sol) and chromatin (Chr) extracts from isolated intestinal villus and crypt cells in 2-month-old mCherry-H4 transgenic mice. (F) Western Blot analysis of chromatin fraction from mCherry- $\mathrm{H} 4$ transfected HCT-116 cells. (G) Pulldown assay using GST-SUMO IKBa protein and chromatin lysates from 2-month-old WT mice villi.

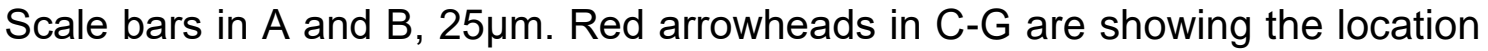
of truncated histone $\mathrm{H} 4$.

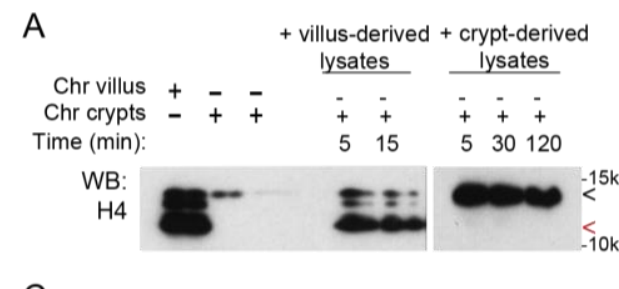

C

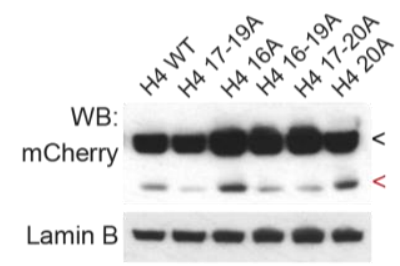

$\mathrm{D}$

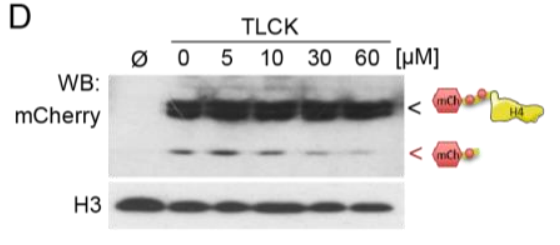

E

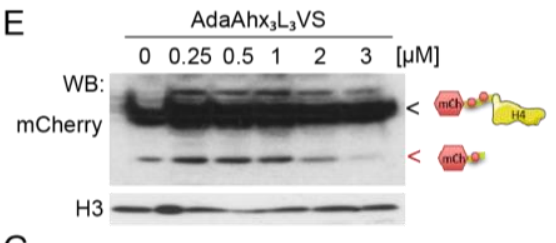

G Inhibitor cocktail: $\frac{\mathrm{P} 1}{\mathrm{P}+-} \frac{\mathrm{P} 2}{\mathrm{P}+-} \frac{\mathrm{P} 3}{\mathrm{P}+-} \frac{\mathrm{P} 4}{\mathrm{P}+-} \frac{\mathrm{P} 5}{\mathrm{P}+-\frac{\mathrm{P} 6}{\mathrm{P}+-}} \frac{\mathrm{P} 7}{\mathrm{P}+-\frac{\mathrm{P} 8}{\mathrm{P}+-}} \frac{\mathrm{P} 9}{\mathrm{P}+-}$ 㝕 $\begin{gathered}\text { Soluble proteins } \\ \text { from villi }\end{gathered}$
B

\begin{tabular}{|c|c|c|}
\hline Protease Family & Protein name & Predicted Cleavage site $(\mathbf{P} 1)$ \\
\hline Serine Proteases & $\begin{array}{l}\text { Cela, pancreatic elastases and endopeptidases } \\
\text { Ctcr, chymotrypsin C } \\
\text { Ephx1, epoxide hydrolase } \\
\text { Hsp } 90 \text {, heat shock protein } 90 \mathrm{kDa} \\
\text { Immp11, mitochondrial signal peptidase } \\
\text { Rhbdd1, rhomboid-like protein } 1 \\
\text { Senp, sentrin/SUMO proteases } \\
\text { Tpsg1, tryptase gamma } \\
\text { Try, trypsin } \\
\text { Uchl, ubiquitin c-terminal hydrolases }\end{array}$ & $3,5,8,12,16,17,19,20$ \\
\hline Cysteine Proteases & $\begin{array}{l}\text { Capn, calpains } \\
\text { Cts, cathepsins } \\
\text { Ggn, gamma-glutamyl hydrolase }\end{array}$ & $\begin{array}{l}99 \\
27\end{array}$ \\
\hline Metalloproteases & $\begin{array}{l}\text { Cpa, carboxypeptidases } \\
\text { Lnpep, leucyl-cystinyl aminopeptidase } \\
\text { Metap, methionyl aminopeptidases } \\
\text { Mmp16, MT3-MMP } \\
\text { Taf2, TBP-associated factor } 2\end{array}$ & \\
\hline
\end{tabular}

$\mathrm{F}$



$\mathrm{H}$

Figure 4. Cleavage of the $\mathrm{N}$-terminal tail of $\mathrm{H} 4$ is mediated by chymotrypsin and trypsin activity present in the intestinal villus. (A) Western Blot analysis of the crypt-derived chromatin fractions incubated with soluble lysates from villi or crypts for the indicated times. (B) Table showing the 
proteases differentially expressed in the villus compartment as determined by RNA-seq analysis of intestinal crypt (purified EphB2 high cells) and villus (EphB2 negative/low) cells. Predicted cleavage sites for each protease in the histone $\mathrm{H} 4$ sequence was determined using the PeptideCutter-ExPASy and PROSPER software. (C) Western blot analysis of mCherry-H4 with the indicated mutations transfected in HCT-116 cells. (D, E) Western Blot analysis of mCherry-H4 transfected in HCT-116 cells treated for 16 hours with TLCK (D) or $A d a A h x_{3} L_{3} V S(E)$ at the indicated concentrations. (F) Western blot analysis of chromatin extracts from post-confluent HT29 cells treated as indicated. (G) Western Blot analysis of a cleavage experiment incubating modified $\mathrm{H} 4$ peptides (P1-P9) with soluble lysates from villi or crypts in the presence $(+)$ or absence (-) of the commercial protease inhibitors cocktail. Lanes indicated as $P$ correspond to the control peptide without lysate incubation. Notice the electrophoretic shift of peptides incubated with villus lysates (compared with control peptides) suggestive of their binding to proteins absent from crypt lysates. $(\mathrm{H})$ Quantification of the relative cleavage of specific $\mathrm{H} 4$ peptides incubated with villus-derived lysates from 3 independent experiments performed. Red arrowheads in A, C-F indicate truncated histone $\mathrm{H} 4$. 
A

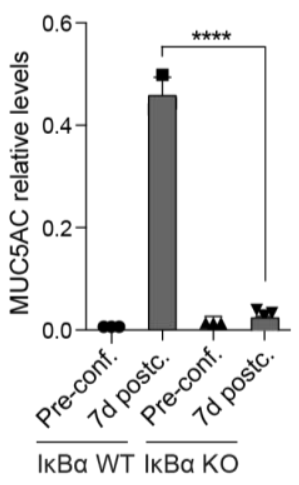

C

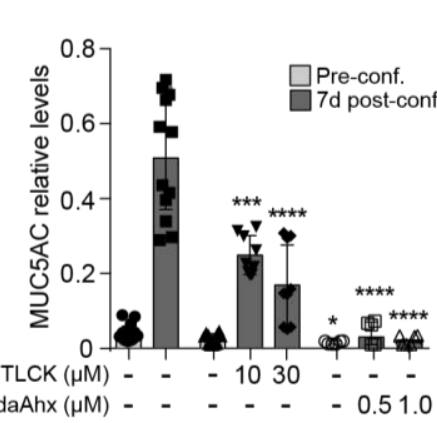

B

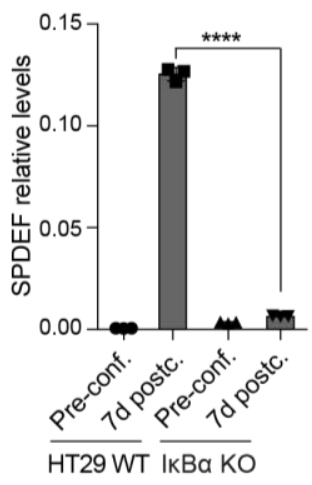

D

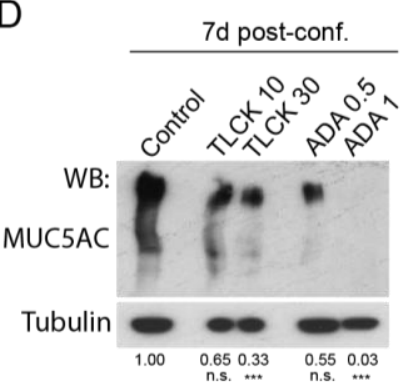

G
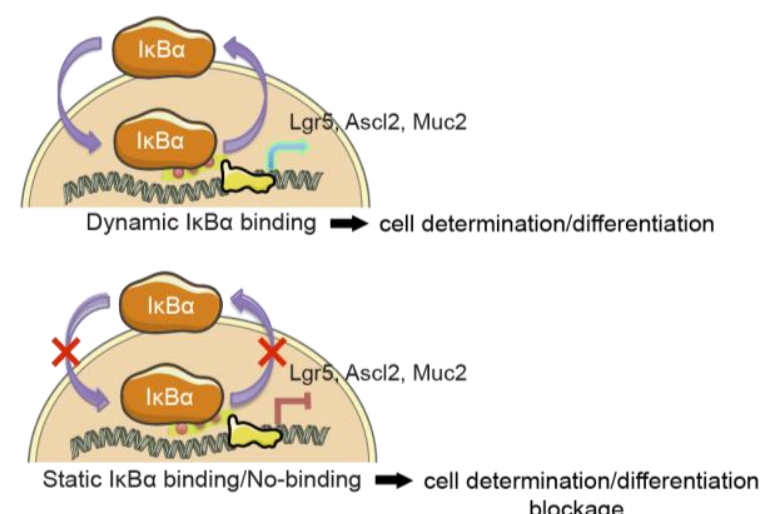
blockage

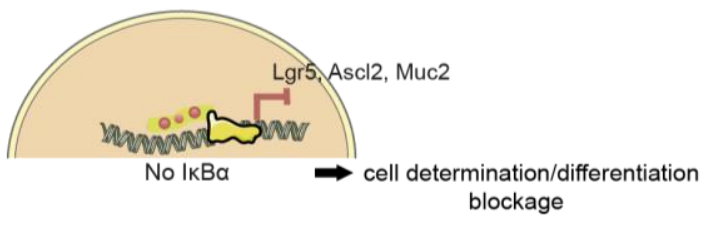

Figure 5. Functional impact of IKBa chromatin binding dynamics in cell differentiation. (A, B) qPCR $(A)$ and WB analysis $(B)$ of the indicated genes or proteins in parental or IKBa KO HT29 cells obtained at pre-confluence or 7 days post-confluence. (C, D) qPCR (C) and WB analysis (D) of MUC5AC in HT29 cells treated with the indicated protease inhibitors. (E, F) qPCR (E) and WB analysis (F) of MUC5AC in HT29 cells transduced with sh-RNAs against trypsin $(\mathrm{T} 1, \mathrm{~T} 2)$ or chymotrypsin $(\mathrm{C} 1, \mathrm{C} 2)$. (G) Model for gene regulation by chromatinassociated IKBa. In brief, dynamic dissociation of $\mathrm{IKBa}$ from the chromatin at 
specific genetic loci promotes transcription of genes involved in stem cell maturation or differentiation (upper panel). Absence of dynamic binding (middle panel) or cells IKBa deficient (lower panels) fail to activate IKBa-dependent transcription thus imposing a differentiation/maturation blockage. Images in A-F are representative of three independent replicates performed. $p$ values were derived from unpaired two-tailed $t$-test, ${ }^{* * *} p$-value $<0.001,{ }^{* *} p$-value $<0.01,{ }^{*} p$ value $<0.05$, n.s. no significant.

\section{REFERENCES}

Aguilera, C., Hoya-Arias, R., Haegeman, G., Espinosa, L., and Bigas, A. (2004). Recruitment of IKBa to the hes1 promoter is associated with transcriptional repression. Proc. Natl. Acad. Sci. U. S. A. 101.

Anders, S., Pyl, P.T., and Huber, W. (2015). HTSeq-A Python framework to work with high-throughput sequencing data. Bioinformatics.

Arenzana-Seisdedos, F., Turpin, P., Rodriguez, M., Thomas, D., Hay, R.T., Virelizier, J.L., and Dargemont, C. (1997). Nuclear localization of IkBa promotes active transport of NF-kB from the nucleus to the cytoplasm. J. Cell Sci.

Bours, V., Franzoso, G., Azarenko, V., Park, S., Kanno, T., Brown, K., and Siebenlist, U. (1993). The oncoprotein Bcl-3 directly transactivates through KB motifs via association with DNA-binding p50B homodimers. Cell.

Brena, D., Bertran, J., Porta-de-la-Riva, M., Guillén, Y., Cornes, E., Kukhtar, D., Campos-Vicens, L., Fernández, L., Pecharroman, I., García-López, A., et al. (2020). Ancestral function of Inhibitors-of-kappaB regulates Caenorhabditis elegans development. Sci. Rep.

Culver, C., Sundqvist, A., Mudie, S., Melvin, A., Xirodimas, D., and Rocha, S. (2010). Mechanism of Hypoxia-Induced NF-kB. Mol. Cell. Biol.

Desterro, J.M., Rodriguez, M.S., and Hay, R.T. (1998). SUMO-1 modification of IkappaBalpha inhibits NF-kappaB activation. Mol. Cell.

Dow, L.E., O’Rourke, K.P., Simon, J., Tschaharganeh, D.F., Van Es, J.H., Clevers, H., and Lowe, S.W. (2015). Apc Restoration Promotes Cellular Differentiation and Reestablishes Crypt Homeostasis in Colorectal Cancer. Cell.

Duncan, E.M., Muratore-Schroeder, T.L., Cook, R.G., Garcia, B.A., Shabanowitz, J., Hunt, D.F., and Allis, C.D. (2008). Cathepsin L Proteolytically Processes Histone H3 During Mouse Embryonic Stem Cell Differentiation. Cell.

Dyer, P.N., Edayathumangalam, R.S., White, C.L., Bao, Y., Chakravarthy, S., Muthurajan, U.M., and Luger, K. (2003). Reconstitution of Nucleosome Core Particles from Recombinant Histones and DNA. Methods Enzymol.

Espinosa, L., Inglés-Esteve, J., Aguilera, C., and Bigas, A. (2003).

Phosphorylation by glycogen synthase kinase-3 $\beta$ down-regulates Notch activity, a link for Notch and Wnt pathways. J. Biol. Chem. 278. 
Filippakopoulos, P., Picaud, S., Mangos, M., Keates, T., Lambert, J.P., BarsyteLovejoy, D., Felletar, I., Volkmer, R., Müller, S., Pawson, T., et al. (2012). Histone recognition and large-scale structural analysis of the human bromodomain family. Cell.

Hendriks, I.A., D'Souza, R.C.J., Yang, B., Verlaan-De Vries, M., Mann, M., and Vertegaal, A.C.O. (2014). Uncovering global SUMOylation signaling networks in a site-specific manner. Nat. Struct. Mol. Biol.

Hirotani, T., Lee, P.Y., Kuwata, H., Yamamoto, M., Matsumoto, M., Kawase, I., Akira, S., and Takeda, K. (2005). The Nuclear IkB Protein IkBNS Selectively Inhibits Lipopolysaccharide-Induced IL-6 Production in Macrophages of the Colonic Lamina Propria. J. Immunol.

Hoffmann, J., and Akira, S. (2013). Innate immunity. Curr. Opin. Immunol. Huang, H., Lin, S., Garcia, B.A., and Zhao, Y. (2015). Quantitative proteomic analysis of histone modifications. Chem. Rev.

Kim, D., Pertea, G., Trapnell, C., Pimentel, H., Kelley, R., and Salzberg, S.L. (2013). TopHat2: Accurate alignment of transcriptomes in the presence of insertions, deletions and gene fusions. Genome Biol.

Kim, K., Punj, V., Kim, J.M., Lee, S., Ulmer, T.S., Lu, W., Rice, J.C., and An, W. (2016). MMP-9 facilitates selective proteolysis of the histone $\mathrm{H} 3$ tail at genes necessary for proficient osteoclastogenesis. Genes Dev.

Levenstein, M.E., and Kadonaga, J.T. (2002). Biochemical analysis of chromatin containing recombinant Drosophila core histones. J. Biol. Chem.

Love, M.I., Huber, W., and Anders, S. (2014). Moderated estimation of fold change and dispersion for RNA-seq data with DESeq2. Genome Biol.

Marruecos, L., Bertran, J., Guillén, Y., González, J., Batlle, R., LópezArribillaga, E., Garrido, M., Ruiz-Herguido, C., Lisiero, D., González-Farré, M., et al. (2020). IkBa deficiency imposes a fetal phenotype to intestinal stem cells. EMBO Rep.

Melo, F.R., Wallerman, O., Paivandy, A., Calounova, G., Gustafson, A.M., Sabari, B.R., Zabucchi, G., Allis, C.D., and Pejler, G. (2017). Tryptase-catalyzed core histone truncation: A novel epigenetic regulatory mechanism in mast cells. J. Allergy Clin. Immunol.

Mulero, M., Ferres-Marco, D., Islam, A., Margalef, P., Pecoraro, M., Toll, A., Drechsel, N., Charneco, C., Davis, S., Bellora, N., et al. (2013). Chromatinbound IKBa regulates a subset of polycomb target genes in differentiation and cancer. Cancer Cell 24.

Rao, P., Hayden, M.S., Long, M., Scott, M.L., West, A.P., Zhang, D., Oeckinghaus, A., Lynch, C., Hoffmann, A., Baltimore, D., et al. (2010). IkB $\beta$ acts to inhibit and activate gene expRao, P., Hayden, M.S., Long, M., Scott, M.L., West, A.P., Zhang, D., Oeckinghaus, A., Lynch, C., Hoffmann, A., Baltimore, D., et al. (2010). IkB $\beta$ acts to inhibit and activate gene expression during the inflammator. Nature.

Song, J., Tan, H., Perry, A.J., Akutsu, T., Webb, G.I., Whisstock, J.C., and Pike, 
R.N. (2012). PROSPER: An Integrated Feature-Based Tool for Predicting Protease Substrate Cleavage Sites. PLoS One.

Vossaert, L., Meert, P., Scheerlinck, E., Glibert, P., Van Roy, N., Heindryckx, B., De Sutter, P., Dhaenens, M., and Deforce, D. (2014). Identification of histone H3 clipping activity in human embryonic stem cells. Stem Cell Res.

Wilkins, M.R., Gasteiger, E., Bairoch, A., Sanchez, J.C., Williams, K.L., Appel, R.D., and Hochstrasser, D.F. (1999). Protein identification and analysis tools in the ExPASy server. Methods Mol. Biol.

\section{ACKNOWLEDGEMENTS}

We want to thank the Bigas' and Espinosa's lab members for constructive discussions and suggestions and technical support. This work has been funded by Instituto de Salud Carlos III FEDER (PI19/0013), Agencia Estatal de Investigación, Spain (PID2019-104695RB-I00) to A.B., NIH/GM085490 to G.G., BIO2017-83650-P to JVF and Generalitat de Catalunya 2017SGR135. LM is a predoctoral fellow of 2015FI-B00806 and 2016FI-B1 00110 and MF has financial support by the Universitat de Vic-Universitat Central de Catalunya PhD fellowships program. The authors thankfully acknowledge the computer resources at Pirineus and the technical support provided by the Spanish Supercomputer Network (BCV-2020-1-0001). 


\section{Supplemental Material}

\section{SUPPLEMENTARY FIGURES AND LEGENDS}

A

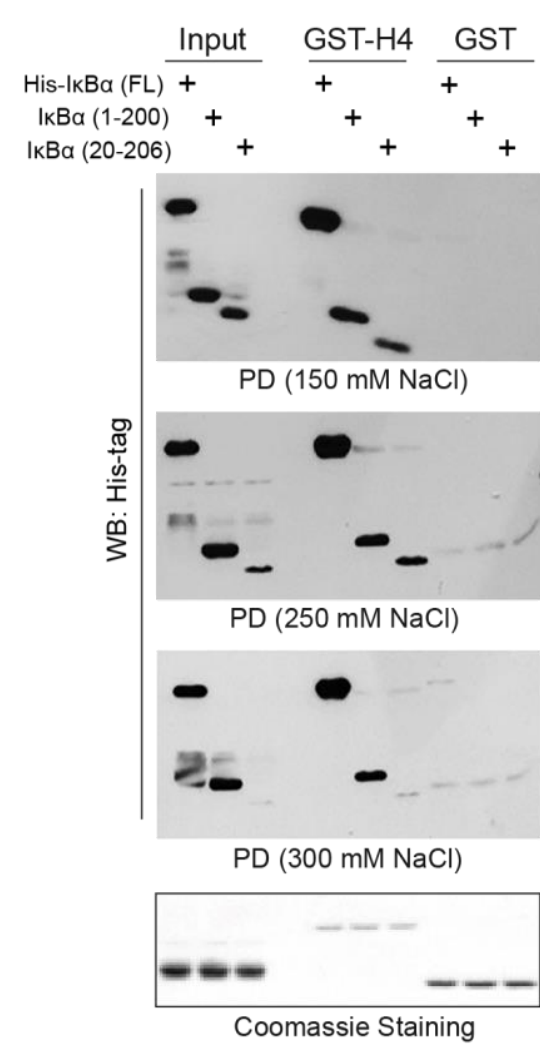

B

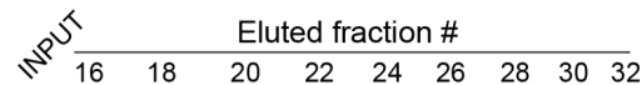

$\triangleleft \mathrm{H} 2 \mathrm{~A}$
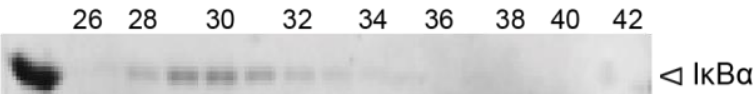

(aa1-200)

$\begin{array}{lllllllll}13 & 15 & 17 & 19 & 21 & 23 & 25 & 27 & 29\end{array}$

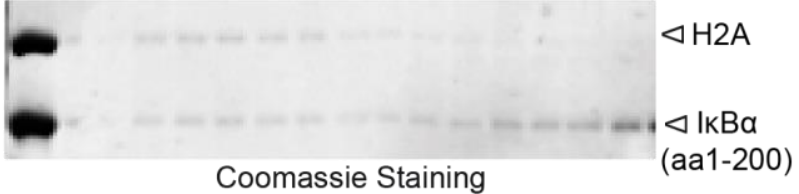

C

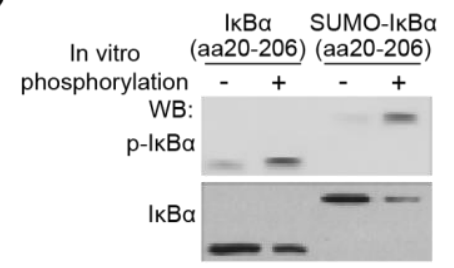

Figure S1. In vitro interactions and phosphorylation of IKBa. (A) PD experiments under different salt concentrations using GST-H4 as bait and the indicated IKB $\alpha$ constructs expressed in HEK-293T cells. (B) Coomassie staining analysis of the indicated fractions recovered in the Fast Protein Liquid Chromatography (FPLC) analysis of $1 \mathrm{KBa}$ and histone H2A complexes. (C) Western blot analysis of IKBa phosphorylated in vitro by addition of active IKK $\beta$ kinase with anti-p-IKBa (S32-36) antibody. 


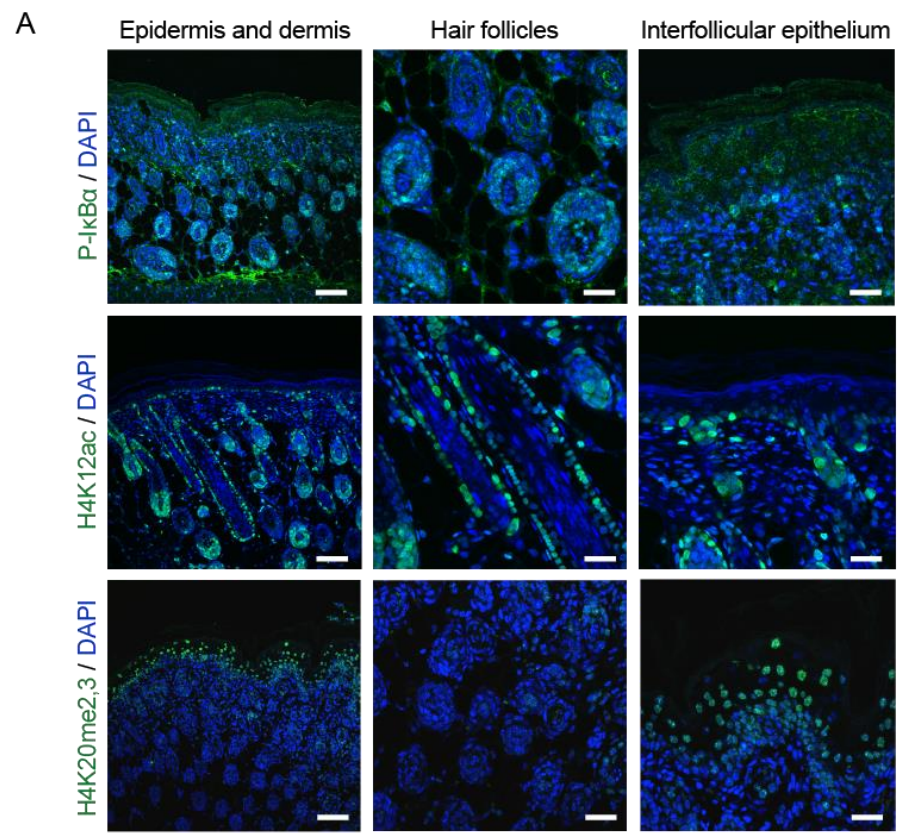

B
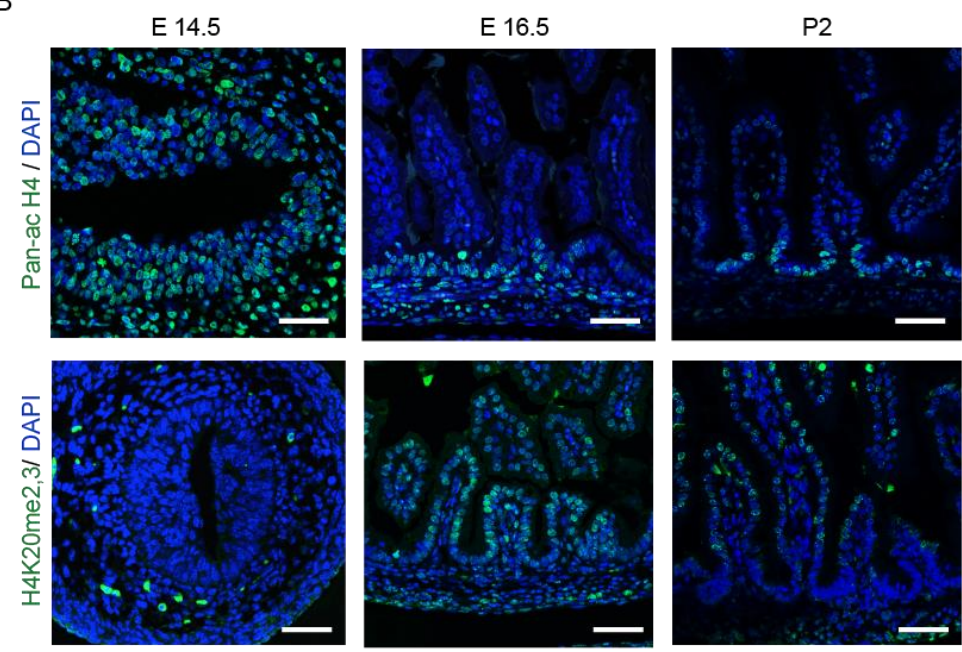

Figure S2. IKBa is localized in stem cell compartments. (A, B) IF analysis with the indicated antibodies in sections from murine skin of 2-month-old mice (A) and sections from small intestine of mice at different stages of development (B). Scale bars in A and B, $25 \mu \mathrm{m}$.

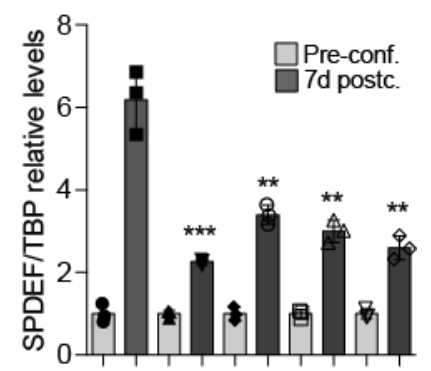

Contr-shRNA + + - - - - - -

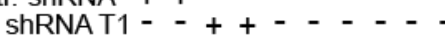

ShRNAT2 - - - + + - -

ShRNAC1 - - - - - + + -

shRNA T1+C2 - - - - - - + + 
Figure S3. Inhibition of goblet cell differentiation by trypsin or chymotrypsin knock-down. Analysis by qPCR of SPDEF in HT29 cells transduced with specific shRNA against trypsin $(T)$ or chymotrypsin $(C)$ at preconfluence or 7 days after confluence. 